\title{
EFFECT OF MARINE CYANOBACTERIA ON CIGARETTE SMOKE EXPOSED MICE -A PRELIMINARY REPORT
}

\author{
Thirunalasundari $\mathrm{T}^{1}$ and Antony V. Samrot ${ }^{2}$ \\ 1Department of Biotechnology, Bharathidasan University, Tiruchirappalli - 620024 \\ 2Sathyabama University, Rajiv Gandhi Salai, Sholinganallur, Chennai - 600119
}

\begin{abstract}
There is sound evidence that cigarette smoking represents a major risk factor causing oxidative stress leads to cancer at various site and many other chronic degenerative diseases. To have an understanding about this we studied the biochemical, immunological and haematological changes accompanying cigarette smoke induced stress in mice and this in turn is followed by treatment with Oscillatoria willei extract. The overall results revealed some stress related pathological changes in the mice model exposed to cigarette smoke. Interestingly some of the cigarette smoke induced stress changes were brought back to normal when Oscillatoria willei extract was given to the cigarette smoke exposed mice.

Keywords: Oscillatoria willei, cigarette smoke
\end{abstract}

\section{INTRODUCTION}

Tobacco smoking is being practiced in the form of cigar biddies etc to a minor extend in certain regions only (3) and these tobacco smoke is a human lung carcinogen, as well as also a major risk factor for oral, pharyngeal, colo rectal and oesophageal cancers $(4,6)$. Epidemiological studies suggested that about 1.2 to $1.4 \%$ of risk for passive smokers (1). The chemical constituents of tobacco are Acetaldehyde, Acetone, Acrolein, Acrylonitrile, Ammonia, Benzene, Benzo (a) pyrene, Bicyclohexyl, Crotonaldehyde, Cyclopentane, Cyclohexane, Hydrazine, Hydrogencyanide, Methylamine, Methyl Chloride, Methylpyrazines, Tar, Trimethylamine, Urethane and Vinylchloride etc. (7).. These chemicals elevate the level of reactive oxygen species (ROS) which leads to cell damage and malfunction through the free radical mediated decomposition of vital molecules such as DNA, proteins and lipids (2\&8). Increased expression of Cytochrom $\mathrm{P}_{450}$ isozymes, Cytochalasin $\mathrm{B}$ and other drug metabolizing enzymes may influence the carcinogenicity of these substances (10).

Kiecolt-Glaser and Ronald Glaser (11) have reported lower natural killer cells (NK cells) in the smokers. The whole body exposure of BDF1 mice to mainstream cigarette smoke resulted in an evident increase of mononuclear normochromatic erythrocytes in peripheral blood (12). D'Agostini (13) observed a decrease in the macrophage count in mice exposed to cigarette smoke and that too the pulmonary alveolar macrophage undergoing apoptosis.

The potential uses of Marine Cyanobacteria are being given new attention to the World over, in view of their importance in agriculture $(14,15 \& 16)$, industry
(17), environmental pollution abatement (18\&19) and pharmaceutical markets $(20,21,22 \& 23)$.

The antitumor activity of cryptophycin produced by Nostoc sp in human tumor xenograft models were explored (25).

Having gathered the basic information on cigarette smoke induced stress on animal models \& human beings and the bioactive potentials of cyanobacteria, this preliminary study was undertaken by us at NFMC, Department of Microbiology, Bharathidasan University, Tiruchirappalli - 620024.

\section{MATERIALS AND METHODS}

a. Organism chosen: The marine cyanobacterium Oscillatoria willei was obtained from the germplasm collection of the National Facility for Marine Cyanobacteria (NFMC), Department of Microbiology, Tiruchirappalli - 620 024, India. The organism was cultured in ASN III $\mathrm{N}^{+}$media in an auxenic condition (26) and incubated at 1,500 lux. in the germplasm of the facility and used after 15-20 days incubation.

b. Extraction Procedure: The weighed wet mass was ground in a pestle and mortar with $100 \%$ alcohol (distilled) to obtain ethanolic extract. Crude extract was used for the study.

c. Experimental animal chosen for this study: Swiss albino male mice were chosen for this study, were obtained from the animal house of Dept. of Microbiology, Bharathidasan University, Tiruchirappalli - 620024 . The animals were fed with freshly prepared feed containing milk and wheat powder \& salt to taste and tap water ad libitum. 
d. Study Design: The selected mice were divided into 4 groups containing 5 animals each. The control animals (C1) were not exposed to cigarette smoke and next set of control animals (C2) received PBS pH 7.2 from $16^{\text {th }}$ day to $30^{\text {th }}$ day of the study period. Animals of the experimental group (T1) were exposed to cigarette smoke for fifteen (15) days continuously, whereas the next test group (T2) was exposed to cigarette smoke for fifteen days continuously followed by Oscillatoria willei extract for next fifteen (15) days $\left(16^{\text {th }}-30^{\text {th }}\right.$ day). C1 acted as the control for T1 and C2 acted as the control for T2.

e. Exposure to cigarette smoke: Whole body exposure to main stream cigarette smoke was obtained by using commercial cigarette (Scissors TM). The cigarette was allowed to burn in the cage with test group of animals (T1 \& T2). Cigarette smoke induced stress was given to the test groups $\mathrm{T} 1$ and $\mathrm{T} 2$ by burning one Scissors ${ }^{\mathrm{TM}}$ cigarette per day per cage having 5 animals. This was given for 15 days continuously. The cages were closed while exposing the animals to cigarette smoke. After treatment the test group animals were allowed to inhale fresh air.

f. Treatment dose: Crude Oscillatoria willei extract was given intraperitoneally $(\mathrm{IP})$ at a concentration of $25 \mu \mathrm{g} /$ day/animal for 15 days continuously to test group animals (T2) after cigarette smoke exposure i.e. from $16^{\text {th }}$ day to $30^{\text {th }}$ day. The $\mathrm{C} 2$ animals were given with PBS pH $7.225 \mu$ //day/animal from $16^{\text {th }}$ to $30^{\text {th }}$ day, as PBS pH 7.2 happened to be the suspending medium of crude extract of Oscillatoria willei extract.

g. Analysis- The animals were watched regularly for their general health condition, feed intake, water intake, excretion quantity and whole bodyweight. After the study period ( 15 days \& 30 days) the animals were analyzed for hematological \& immunological parameters. At the time of dissection the haematological parameters like bleeding time, clotting time, total count of erythrocytes (RBC) \& leukocytes (WBC), differential count and hemoglobin content were seen. Total count of RBC and WBC were made using Neubauer's chamber according to Thomson \& Inwood (1976) (27) and hemoglobin content was determined adopting the method of Oser (1965) (28). Gravimetric analysis of the various organs, primary lymphoid organs and secondary lymphoid tissues were seen by making use of an electronic balance (Sartorius). Immunoreactive cell count was also done with the help of hemocytometer and microscope. The treatment groups were analysed by Mean \pm Standard Error.

\section{RESULTS}

There were no observable changes phenotypically like hair falling, itching etc. Test groups were on par with the control group animals as far as the general health condition and body weight was concerned (Table 1) (fig.1).

There was a reduction in feed consumption of T2 group of animals and the reduction was roughly around $1 \%$ only (fig.2). The intake of water was found to be doubled in $\mathrm{T} 1$ compared to the control $\mathrm{C} 1$ and $\mathrm{C} 2$. Though there was an increase in the intake of water in T2, it was lower than that of T1 (fig.3). Contradictory to the water intake there was a drastic change in the quantity of excreta of mice between control groups \& test groups and the decrease was greater in test groups T1 and T2 (fig. 4).

The time interval between the prick time (the bleeding start) and the bleeding stop is the bleeding time. Here in this study the bleeding time was decreased more than $50 \%$ in test groups $\mathrm{T} 1$ and $\mathrm{T} 2$ compared to the control groups $\mathrm{C} 1$ and $\mathrm{C} 2$. Roughly around $60 \%$ decrease was noted in the bleeding time of T2 compared to control C2. But the difference between the test groups T1 and T2 was around 1\% only (fig. 5). On the other hand the clotting time of $\mathrm{T} 1$ was almost equal to the control groups C1 and C2. The clotting time of T2 was lower than that of control $\mathrm{C} 1, \mathrm{C} 2$ and $\mathrm{T} 1$ (fig. 6).

WBC count was found to be increased in T1 and T2 compared to the control $\mathrm{C} 1$ and $\mathrm{C} 2$ (fig. 7). Fig. 8 showed an increase in the RBC count of T1 than that of control $\mathrm{C} 1$ and $\mathrm{C} 2$, whereas the RBC count of T2 was equal to control $\mathrm{C} 2$ and lower than T1. There was an increase in neutrophil count (10\%) in T1 than the control groups C1. Lymphocyte count was decreased in the test groups T1 and T2. Monocyte \& lymphocyte count of T2 was enhanced compared to T1 showing the recovery from the cigarette smoke induced stress in mice (fig. 9a, 9b, 9c). Though there was a change in the hemoglobin level of all the animals the difference was not statistically significant (fig. 10). 
The gravimetric analysis revealed $40 \%$ reduction in liver and $25 \%$ reduction in kidney between $\mathrm{T} 2 \& \mathrm{C} 2$. But the immune system of both the test groups showed an increased weight than the control groups $\mathrm{C} 1$ and $\mathrm{C} 2$ (Table 2).

The gravimetric analysis of primary lymphoid organ showed difference in T1 and T2 compared to control. The secondary lymphoid tissue showed an enhancement in the gravimetry of T1 and T2 saying that the animals has responded to the treatment, smoke as well as smoke followed by cyanobacterial extract (Table 3). The immunoreactive cells count of thymus was decreased in test groups T1 and T2 compared to the

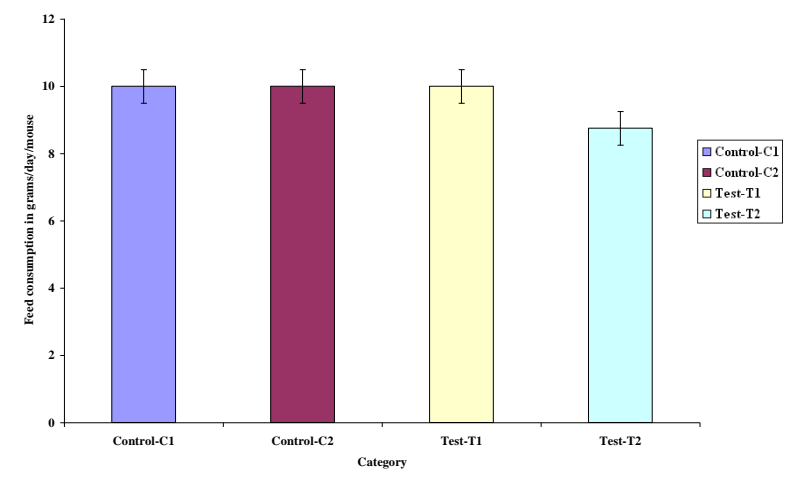

Fig.1. Morphometric Analysis

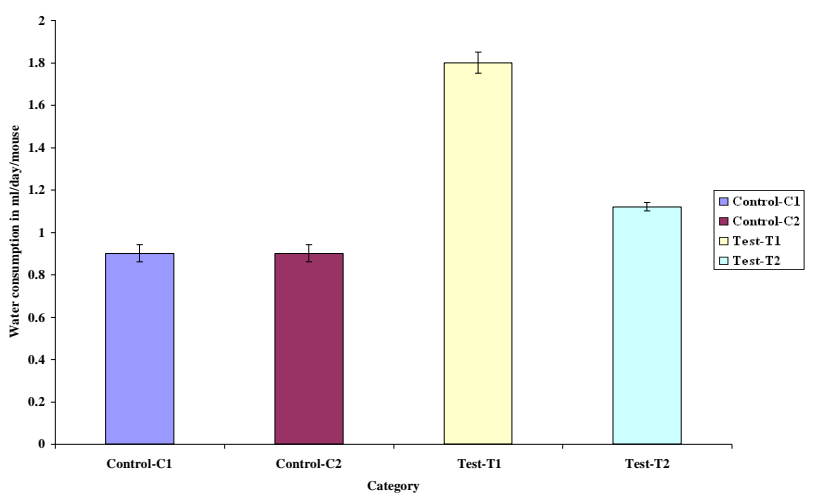

Fig.3. Water Intake control C1. Contradictory to this the cell count of various lymphnodes studied showed increased cell count in T1 \& T2 than that of control group C1 (Table 4).

\section{Table 1. Phenotypic Changes - General Health Condition}

\begin{tabular}{|l|l|}
\hline \multicolumn{1}{|c|}{ OBSERVATION } & RESULTS \\
\hline Color change & No change \\
Hair Falling & No change \\
Any other & No change \\
\hline
\end{tabular}

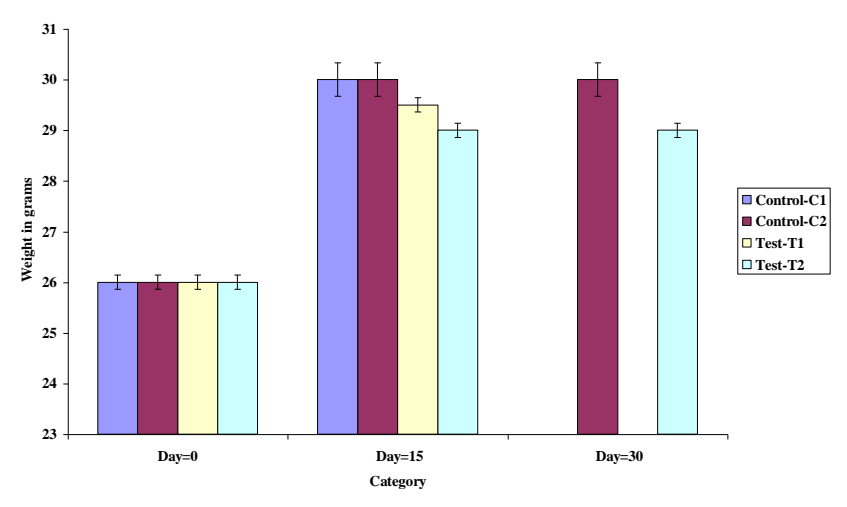

Fig.2. Feed Consumption

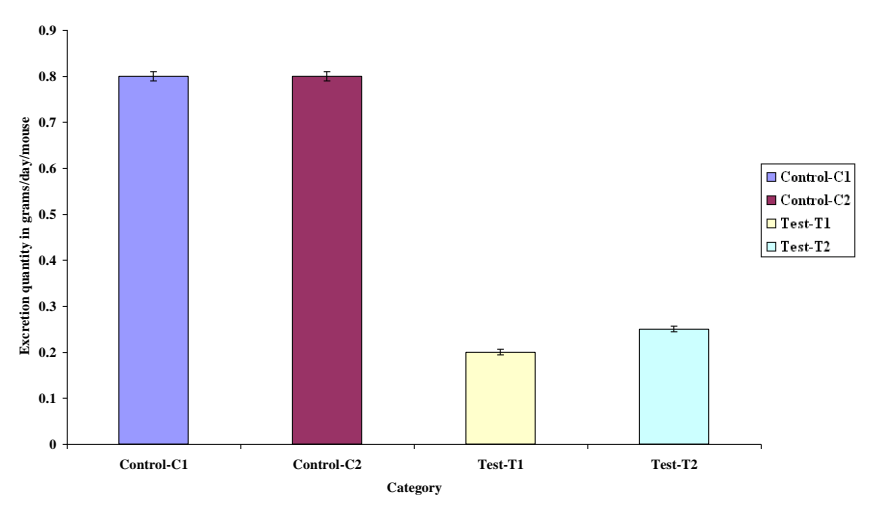

Fig.4. Quantity of Excreta 


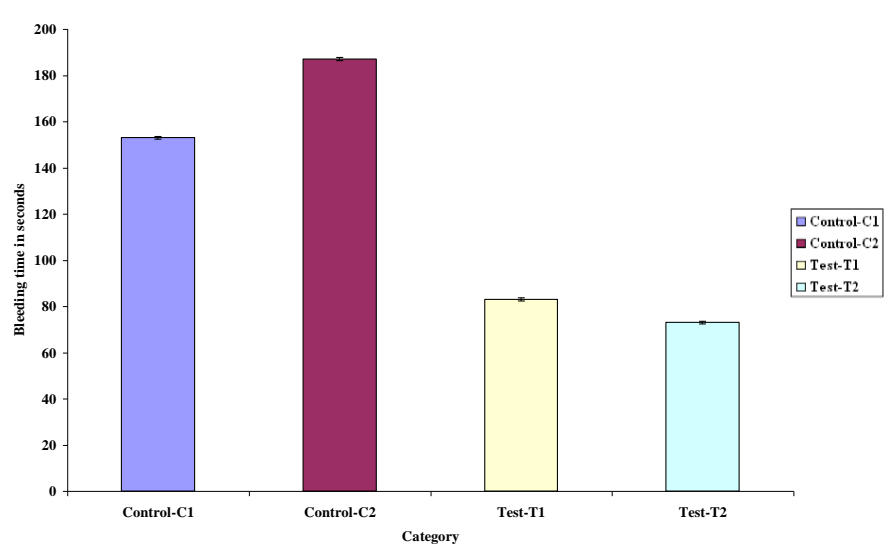

Fig.5. Bleed Time

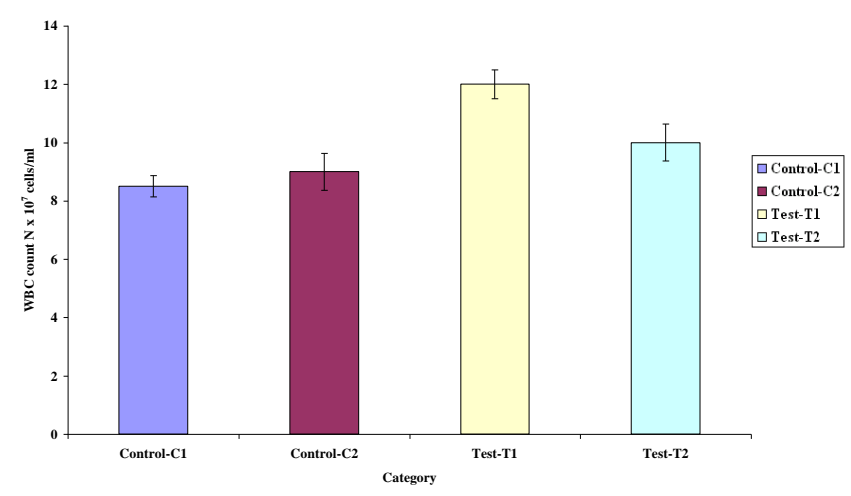

Fig.7. Total WBC Count

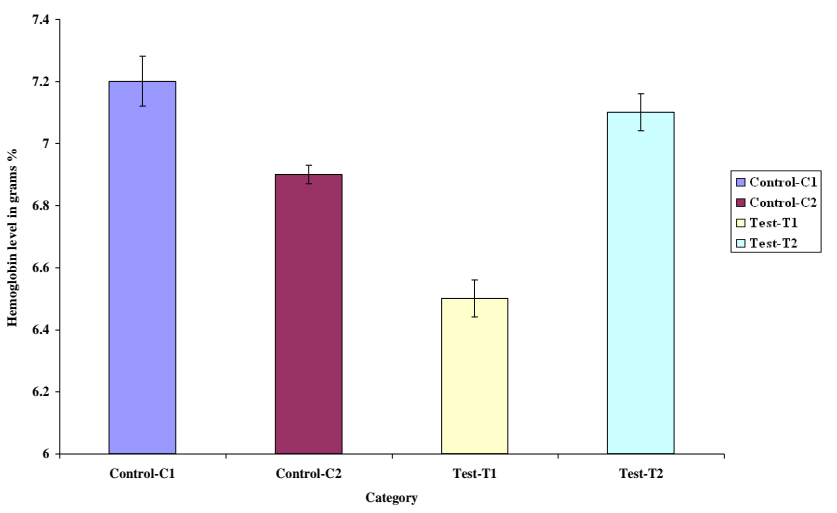

Fig.9. Differential Count

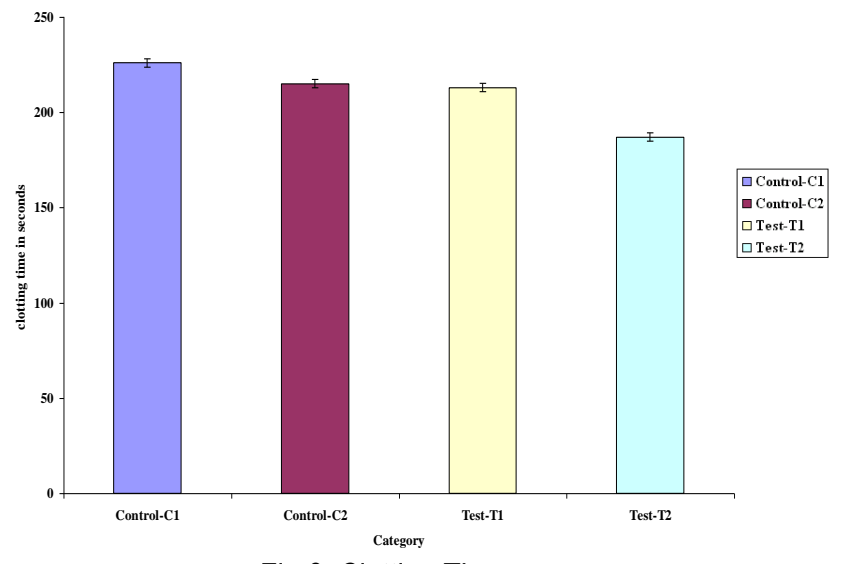

Fig.6. Clotting Time

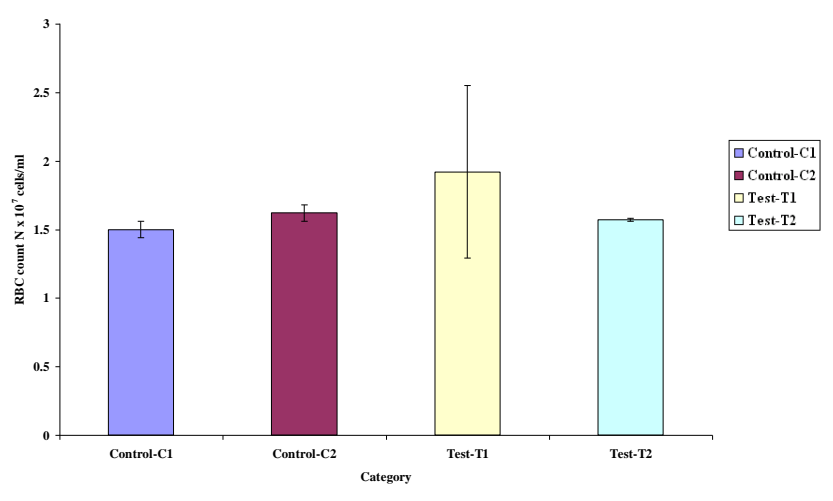

Fig.8. Total RBC Count

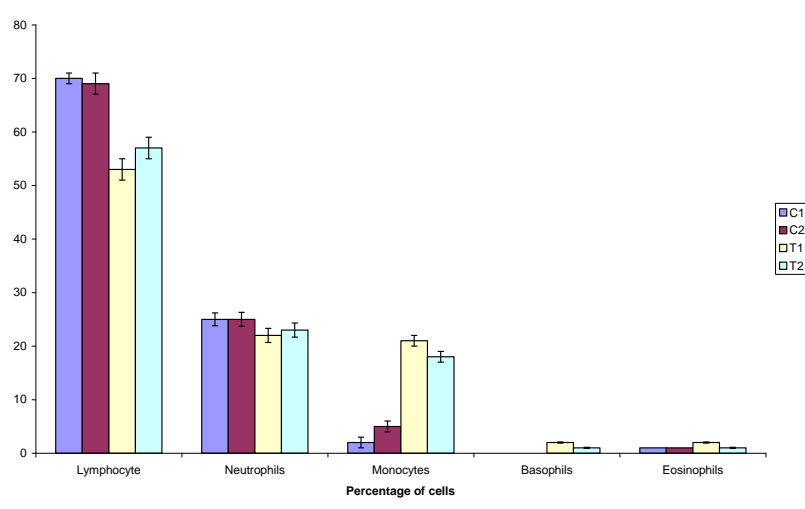

Fig.10. Haemoglobin Level 
Table 2: Gravimetric Analysis of Organ/System Weights

\begin{tabular}{|c|c|c|c|c|c|}
\hline S. No & Organs/System & \multicolumn{4}{|c|}{ Weight in gms. } \\
\cline { 3 - 6 } & & Control (C1) & $\begin{array}{c}\text { Control } \\
\text { (C2) }\end{array}$ & $\begin{array}{c}\text { Test } \\
\text { (T1) }\end{array}$ & $\begin{array}{c}\text { Test } \\
\text { (T2) }\end{array}$ \\
\hline 1. & Liver & $1.425 \pm 0.057$ & $2.071 \pm 0.054$ & $1.261 \pm 0.054$ & $1.383 \pm 0.063$ \\
\hline 2. & Lungs & $0.175 \pm 0.006$ & $0.235 \pm 0.002$ & $0.252 \pm 0.006$ & $0.175 \pm 0.003$ \\
\hline 3. & Kidney & $0.354 \pm 0.016$ & $0.426 \pm 0.006$ & $0.322 \pm 0.002$ & $0.305 \pm 0.002$ \\
\hline 4. & Spleen & $0.082 \pm 0.006$ & $0.062 \pm 0.002$ & $0.071 \pm 0.001$ & $0.062 \pm 0.002$ \\
\hline 5. & Immune system & $0.128 \pm 0.002$ & $0.125 \pm 0.006$ & $0.147 \pm 0.006$ & $0.133 \pm 0.001$ \\
\hline
\end{tabular}

Table 3: Gravimetric Analysis of Immune System

(Weight in $\mathrm{mg}$ )

\begin{tabular}{|c|c|c|c|c|c|}
\hline \multirow{2}{*}{ S. No } & Organs/Tissues & \multicolumn{4}{|c|}{ Weight in mg. } \\
\cline { 3 - 5 } & & $\begin{array}{c}\text { Control } \\
\text { (C1) }\end{array}$ & $\begin{array}{c}\text { Control } \\
(\mathbf{C 2})\end{array}$ & $\begin{array}{c}\text { Test } \\
\text { (T1) }\end{array}$ & $\begin{array}{c}\text { Test } \\
\text { (T2) }\end{array}$ \\
\hline 1. & Thymus & $25.6 \pm 0.457$ & $24 \pm 0.245$ & $28.5 \pm 0.480$ & $24 \pm 0.362$ \\
\hline 2. & Spleen & $72.6 \pm 0.006$ & $61.5 \pm 0.480$ & $70.5 \pm 0.480$ & $61.5 \pm 0.630$ \\
\hline 3. & Inguinal lymphnode & $13.4 \pm 0.002$ & $14 \pm 0.006$ & $18 \pm 0.006$ & $19 \pm 0.003$ \\
\hline 4. & Auxiliary lymphnode & $8.4 \pm 0.006$ & $14.5 \pm 0.006$ & $16 \pm 0.002$ & $17.5 \pm 0.002$ \\
\hline 5. & Perivertiberal lymphnode & $7.6 \pm 0.002$ & $11 \pm 0.002$ & $13.5 \pm 0.003$ & $10.5 \pm 0.001$ \\
\hline
\end{tabular}

Table 4: Immunoreactive Cells Count (no. of cells $\times 10^{7} / \mathrm{mm}^{3} / \mathrm{ml}$ )

\begin{tabular}{|c|c|c|c|c|c|c|}
\hline \multirow{2}{*}{$\begin{array}{l}\text { S. } \\
\text { No }\end{array}$} & \multirow{2}{*}{$\begin{array}{c}\text { Test } \\
\text { group }\end{array}$} & Primary Lymphoid & \multicolumn{4}{|c|}{ Secondary Lymphoid Tissues } \\
\hline & & Thymus & Spleen & $\begin{array}{l}\text { Inguinal } \\
\text { lymphnode }\end{array}$ & $\begin{array}{l}\text { Auxiliary } \\
\text { lymphnode }\end{array}$ & $\begin{array}{l}\text { Perivertiberal } \\
\text { lymphnode }\end{array}$ \\
\hline 1. & $\begin{array}{c}\text { Control } \\
\text { C1 }\end{array}$ & $40 \pm 2.4$ & $20 \pm 0.63$ & $2.3 \pm 0.57$ & $1.3 \pm 0.06$ & $1.4 \pm 0.06$ \\
\hline 2. & $\begin{array}{l}\text { Control } \\
\text { C2 }\end{array}$ & $40 \pm 4.8$ & $21.0 \pm 0.57$ & $6 \pm 0.57$ & $8 \pm 0.06$ & $6 \pm 0.05$ \\
\hline 3. & Test T1 & $37 \pm 4.9$ & $37 \pm 0.49$ & $11 \pm 0.63$ & $10 \pm 0.05$ & $8 \pm 0.03$ \\
\hline 4. & Test T2 & $16 \pm 2.4$ & $20 \pm 0.36$ & $10 \pm 0.48$ & $10 \pm 0.04$ & $11 \pm 0.02$ \\
\hline
\end{tabular}

\section{DISCUSSION}

The present study was aimed to find out the effect of Oscillatoria willei extract on modulation induced by cigarette smoke in in - vivo system of mouse model There was an observable change in the body weight of the animals, which was contradictory to the results of D'Agostini et al., (13) and Witschi et al., (29) who have reported the no body weight change in the rat and mice models respectively. On the other hand this is similar to the report of Ashwani Koul (30) and Chunliu et al., (31) where they had done the same on the ferrets and mice models respectively.

The feed consumption of the smoke exposed mice were similar to the control, Ashwani Koul (30) also found the same. The feed consumption of the T2 group animals was less which may be due to the treatment of Oscillatoria willei extract. There was an increase in the 
intake of water by the cigarette smoke exposed animals which was deviating to the report of Ashwani koul (30). The cigarette smoke would have induced the thirstiness of the smoke exposed mouse. Interestingly, there was a decrease in the intake of water by T2 compared to T1 but it was higher than control groups C1 \& C2. The probable reason could be the effect of Oscillatoria willei (i.e.) extract. The quantity of excretory material of both T1 and T2 were drastically decreased in this study could be again due to change in physiology by cigarette smoke. Oscillatoria willei has no effect on the recovery of smoke induced changes.

The increase in bleeding time of the $\mathrm{T} 1$ was observed in this study which may be due to the effect of the chemical constituents of cigarette smoke on the clotting mechanism of the mice. Roughly around $60 \%$ decrease was noted in the bleeding time of T2 compared to $\mathrm{C} 2$, the difference was around $1 \%$ only compared to $\mathrm{T} 1$. This again says that Oscillatoria willei extract does not help in bringing back the changes induced by cigarette smoke.

The effect mounted in the bleeding time was not reflected in the clotting time. There was not much variation in the clotting time between $\mathrm{T} 1$ and $\mathrm{C}$, but it was lowered in T2 group compared to T1 and C2.

There was an increase in WBC count of T1 \& T2 compared to control C1 \& $\mathrm{C} 2$. The increase in WBC count in T1 indicates an impact of the smoke on the defense mechanism of the smoke exposed mice. This is in line with the results shown by Felix and Mary Ko (32). Though there was an increase in WBC count of T2 compare to Control (C1\& C2) it was decreased when compared to T1. This may be due to the action of Oscillatoria willei extract on the defense mechanism of the mice. Sundararaman et al., (33) also reported similar result with 9 other marine cyanobacterial extract. Earlier on the effect of marine cyanobacteria on rat conducted in this lab also showed similar kinds of results (34,35 \& 36) Baojiang et al., (37) also reported that polysaccharide of Spirulina can improve both specific and nonspecific mechanism of immune response.

It was observed that there was an increase in the RBC count of T1 in this study. Balansky et al., (12) also reported increase in peripheral blood erythrocytes in cigarette smoke exposed rats and the difference was statistically significant, which reached the maximum of 2.1 fold increase over control for five week cigarette smoke exposure. Liu et al., (5) also showed an increased angiogenesis in the mice having colistic while exposing to cigarette smoke. Though there was a decrease in the RBC count of T2 compared to T1 it was similar to $\mathrm{C} 1$, showing that the extract had effect on changes caused by cigarette smoke thereby bringing back the pathological effect of cigarette smoke on RBC to normal.

There was a significant increase in neutrophil and monocyte count of T1 compared to control, this may be due to the effect of the chemical constitutes of cigarette smoke (30) \& (38). The neutrophil count was decreased by $9 \%$ on $\mathrm{T} 2$ compared to $\mathrm{T} 1$ which was closer to the count of $\mathrm{C} 1$, showing the capability of Oscillatoria willei extract on recovering it from the cigarette smoke effect. On the other hand the Oscillatoria willei extract have no effect on recovering the monocyte count where it was increased in T1 and T2 when compared to $C$. This indicates that there is a specific $\&$ non specific immune response.

Gravimetric analysis of liver and kidney showed reduction in both the test groups T1 and T2 compared to $\mathrm{C} 1$. Even though the weight of liver of T2 was lesser than $\mathrm{C} 1$ it was higher than $\mathrm{T} 1$, reflecting that $\mathrm{O}$. willei extract has the ability to recover from stress introduced changes by cigarette smoke, which in turn was reflected in the gravimetry of liver.

Gravimetry of immune system was higher in both the test groups T1 and T2 than the control C1, but the weight of immune system of $\mathrm{T} 2$ was lesser than $\mathrm{T} 1$, this showed the efficiency of 0 . willei extract on recovery of mice model from the effect of cigarette smoke on immune system.

Increase in weight of thymus was seen in T1 compared to control $\mathrm{C} 1$, indicates that the compounds of cigarette smoke acts on thymus \& causes megaly of thymus. It was reverted back to normal in 0 . willei extract given animals (T2) and the toxic effect of cigarette smoke was a temporary one. Increased weight of lymphnodes were observed in both the test groups ( $\mathrm{T} 1$ and $\mathrm{T} 2$ ), because both the cigarette smoke \& 0 . willei extract was recognized as antigen by the immune system and processed.

There was a significant reduction in immunoreactive cells count in thymus \& spleen in both T1 \& T2, showed the impact of chemicals in cigarette smoke on thymus \& spleen. O. willei extract has no effect the immunoreactive cells count as in T1.

Immunoreactive cells count of lymphoid tissues (lymphnodes) of both T1 \& T2 showed a significant increase in count. This may be due to the chemicals constituents of cigarette smoke and 0 . willei extract. 
From this preliminary work it was somewhat clear that the extract of 0 . willei has the ability to recover the mice model from stress induced changes on the hematology \& immunology by cigarette smoke.

\section{REFERENCES}

[1] Kenneth $T B$ \& Witschi $H$, Lung tumors in $A / J$ mice exposed to environmental tobacco smoke: estimated potency and implied human risk, Carcinogenesis, 23 (2002) 511.

[2] Teruo I, Hyaashi M, Takayanagi K \& Morooka S, Oxidative DNA damage is induced bychronic cigarette smoking, but repaired by Abstention. J. Health Sci, 49 (2003) 217.

[3] International Agency for Research on Cancer, Tobacco cancer, IARC Monographs on the Evaluation of the Carcinogenic Risk of Chemicals to humans, International Agency for Research on Cancer, Lyon, France, 8 (1986).

[4] Gallus S, Altieri A, Bosetti C, Franceschi S, Levi F, Negri E, Dal Maso L, Conti E, Zambon P \& La Vecchia C, Cigarette tar yield and risk of upper digestive tract cancers: case control studies from Italy and Switzerland, Annals of Oncol, 14 (2003) 209.

[5] Borras J.M, Fernandez E, Gonzalez J R, Negri E, Lucchini $F$, La Vecchia C \& Levi $F$, Lung cancer mortality in European regions (1955-1997), Annals of Oncol, 14 (2003) 159.

[6] Liu E S, Ye Y N, Shin V Y, Yuen S T, Leung S Y, Wong B C \& Cho C H, Cigarette smoke exposure increases ulcerative colitis associated colonic adenoma formation in mice, Carcinogenesis, (2003) ( ahead for printing).

[7] International Agency for Research on Cancer, Tobacco cancer, (1987).

[8] Miller E C, Miller $J$ A,Searches for ultimate chemical carcinogens and their reactions with cellular macromolecules, Cancer,47 (1981) 2327.

[9] Villard P H, Seree E, Lacaralle B, Therene Fenoglio M C, Barra Y, Attolini L., Bruguerole B, Durand $A$, and Catalin $\mathrm{J}$, Effect of cigarette smoke on hepatic and pulmonary cytochromes P450 in mouse evidence for CYP2E1 induction in lung. Biochem. Biophys. Res. Commun.,202 (1994) 1731.

[10] Harryrubin, Synergetic mechanisms in carcinogenesis by polycyclic aromatic hydrocarbons and tobacco smoke: a bio historical perspective with updates, Carcinogenesis, 22(2001) 1903.

[11] Kiecolt- Glaser J \& Ronald Glaser, Psychoneuroimmunology and immumotoxicology: Implications for carcinogenesis. Psychosomatic Med, 61(1999) 271.

[12] Balansky K M, D'Agostini \& De Flora, Induction, persistence and modulation of cytogenetic alterations in cells of smoke exposed mice, Carcinogenesis, 20 (1999) 1491.

[13] D'Agostini F, Balansky R M, Izzotti A, Lubet R A, Kelloff G J \& De Flora S, Modulation of apoptosis by cigarette smoke and cancer chemo preventive agents in the respiratory tract of rats, Carcinogenesis, 22(2001) 375.

[14] Jayaraman S \& Shanmugasundaram S, Algal Biofertilizers: Choice species of Scytonema. In: G. Subramanian. (Ed), Proceedings of National Seminar on Cyanobacterial Research - Indian Scene,( 1993) 24.

[15] Kaushik B D, Cyanobacterial Research - An IARI Pursuit: In: G. Subramanian (Ed). Proceedings of National Seminar on Cyanobacterial Research Indian

(1993) 32.

[16] Subramanian G, Our Tryst with Cyanobacteria In: Subramanian $G(E d)$, Proceedings of National Seminar on Cyanobacterial Research - Indian Scene, (1993) 72 .

[17] Prabaharan D, Sumathy $M$ \& Subramanian G, Ability to use ampicillin as nitrogen source by Marine Cyanobacterium Phormidium valderianum BDU 30501, Current Microbiology 28(1994) 315.

[18] Subramanian G \& Uma L, The Role of Cyanobacteria in Environment management Loic Charpy \& A. W. D. Larkum (Eds). - Bulletin de I' Institut Oceaanographique Marine Cyanobacteria. 19 (1999) 599.

[19] Rama Rao Karna, Uma L, Subramanian G \& Maruthi Mohan $P$, Biosorption of toxic metal ions by alkali - extracted biomass of a Marine Cyanobacterium Phormidium valderianum BDU 30501, World J. Microbiol. \& Biotechnol, 15 (1999) 729.

[20] Thirunalasundari T. \& Subramanian G, Bioactive potentials of Marine Cyanobacteria, In: N. Anand (Ed). Algological Research in India. (Festschrift to 
Prof. V.N. Raja Rao) Bishen Singh Mahendra Pal Singh, Dehra Dun (2000).

[21] Thirunalasundari $T$ \& Subramanian $G$, Pharmacological potentials of Cyanobacteria, In: R.C. Rajak, Biotechnology of Microbes and Sustainable Utilization (Festschrift volume / International symposium on Microbial Biotechnology for sustainable development and productivity) Scientific Publishers (India), Jodhpur (2003) 199.

[22] Gopalakrishnan V, Pramod N P, Sundararaman M, Subramanian G \& Thiyagarajan S P, Antimicrobial properties of Marine Cyanobacteria. In: Subramanian G. Kaushik BD \& Venkataraman G S, (Eds). "Cyanobacterial Biotechnology" Proceedings of the International Symposium, Oxford and IBH Publishers, New Delhi (1998) 456.

[23] Patterson G M L, Biotechnological applications of Cyanobacteria, Journal of Scientific and Industrial Research, August - September 55 (1996) 669.

[24] Krishna Menon, Alvarez E, Forder $P$, Phares $Y$, Amsrud T, Shih C, Al-Awar R, \& Teicher B A, Antitumor activity of cryptophycins: effect of infusion time and combination studies, Chem.Chemother.Pharmacol, 46 (2000) 142.

[25] Teicher B A, Forder P, Menon K, Phares V, Amsrud $T$ \& Shih C, Cryptophycin 52 and cryptophycin 55 in sequential and simultaneous combination treatment regimens in human tumor xenografts, In vivo, 14 (2000) 471.

[26] Rippka R, Duruelles J, Waterbury J B, Herdman M \& Stainer R Y, Generic assignments, Stain histories and properties of pure cultures of Cyanobacteria, J. Gen. Microbiol,111 (1979) 1.

[27] Thomson S \& Inwood M J, Lylches medical laboratory technology Edited by SS Raphel (W.B. Saunders company, London, (1976) 1064.

[28] Oser B L M, Hawk's Physiological Chemistry, TATA McGraw Hill publishing company limited, Bombay New Delhi (1965).

[29] Witschi H, Espiritu I \& Uyeminami D, Chemoprevention of tobacco smoke- induced lung tumors in $\mathrm{A} / \mathrm{J}$ strain mice dietary myo- inositol and dexamethasone, Carcinogenesis, (1999) 20; 1375.

[30] Ashwani Koul, Vipin B \& Bansal M P, Effect of alpha tocopheral on pulmonary antioxidant defense system and lipid peroxidation in cigarette smoke inhaling mice, BMC Biochem. 2 (2001) 14.

[31] Liu C, Wang X D, Bronson R T, Smith D E, Krinsky N I \& Russell M R, Effects of physiological versus pharmacological $\beta$-carotene supplementation on cell proliferation and histopathological changes in the lungs of cigarette smoke exposed ferrets, Carcinogenesis, 12 (2000) 2245.

[32] Felix Ofulue A and Maryko, Effects of depletion of neutrophils and macrophage on development of cigarette smoke induced emphysema, The American Physiological society. (1999) 97.

[33] Sundararaman M, Averal H I, Akbarsha M A \& Subramanian G, Bio - activity of Marine Cyanobacteria in the animal based systems: Modulation of Food intake, body weight and some hematological characters, Ann. Appl. Biol,125 (1994) 195.

[34] Krishnaprema K, Effect of the extract of a Marine Cyanobacterium Oscillatoria willei on Mice, M. Sc. Thesis, Microbiology Department, Bharathidasan University, Tiruchirappalli - 620 024, (1997).

[35] Sunil K D, Antimicrobial compounds from Marine Cyanobacteria with special reference to the Bioactivity of a Purified compound from Oscillatoria laete-virens BDU 20801, Ph.D. Thesis, Microbiology Department, Bharathidasan University, Tiruchirappalli - 620 024, (1999).

[36] Sarulatha S, Immunomodulatory Compound from Marine Cyanobacterium Oscillatoria willei BDU 130511, M. Sc. Thesis, Microbiology Department, Bharathidasan University, Tiruchirappalli - 620 024, (2001).

[37] Baojiang G, Study on effect and mechanism of polysaccharides Spirulina on body immune function improvement, South China Normal Univ. China. Pub. In Proc. Of Second Asia Pacific Conf. On Algal Biotech. Univ. Of Malaysia, China, (1994) 33.

[38] Hasan Yukshel, Ozbiligin K, Coksun S and Tuglu I, Protective effect of leukotriene receptor antagonist montlukent on smoking induced lung injury in Wistar rats, Acta. Med. Okayam, 57 (2003) 13. 